\title{
THE USE OF IMPORTANCE-PERFORMANCE ANALYSIS TO MEASURE THE SATISFACTION OF TRAVEL AGENCY FRANCHISEES
}

\section{Utilização da análise de importância-desempenho para medir a satisfação de franqueados de agências de viagens}

\author{
El uso del importance-performance analysis para medir la satisfacción de \\ franquiciados de agencias de viajes
}

\begin{abstract}
This study contributes to the limited literature on the satisfaction of travel agency franchisees. Specifically, it aims to identify strengths and weaknesses of the system from the perspective of the franchisee. This study would enable franchisors to identify areas in which franchisees are less satisfied. If franchisees are satisfied with numerous aspects that influence the franchisor-franchisee relationship, the latter may have a high degree of loyalty towards their franchisors and this would benefit the entire network. This article uses a variant of the classic importance-performance model from Martilla and James (1977) and others (Ábalo, Varela, \& Rial, 2006; Picón, Varela, \& Braña, 2011). The results show that the attributes travel agency franchisees feel more dissatisfied with are: chain advertising, ongoing support from franchisors, the initial franchisor support, delivery from the franchisors, and training provided by franchisors.
\end{abstract}

KEYWORDS | Satisfaction, importance-performance analysis, franchising, travel agency industry, attributes.

\section{RESUMO}

O presente estudo contribui para a limitada literatura sobre satisfação de franqueados de agências de viagens. Mais especificamente, destina-se a identificar os pontos fortes e fracos do sistema, da perspectiva do franqueado. Este estudo permitiria aos franqueadores identificar as áreas em que os franqueados estão menos satisfeitos. Se os franqueados estão satisfeitos com numerosos aspectos que influenciam o relacionamento franqueador-franqueado, este pode ter um alto grau de lealdade para com seus franqueadores, o que beneficiaria toda a rede. $O$ artigo utiliza uma variação do clássico modelo importância-desempenho de Martilla e James (1977) e outros (Ábalo, Varela, \& Rial, 2006; Picón, Varela, \& Braña, 2011). Os resultados mostram que os atributos com os quais os franqueados de agências de turismo sentem-se mais insatisfeitos são: propaganda da rede, suporte continuado por parte do franqueador, suporte inicial pelo franqueador, cumprimento efetivo por parte do franqueador, e treinamento fornecido pelo franqueador.

PALAVRAS-CHAVE / Satisfação, análise de importância-desempenho, franquia, indústria de agências de turismo, atributos.

\section{RESUMEN}

El presente estudio contribuye a la limitada literatura sobre la satisfacción de franquiciados de agencias de viajes. Específicamente, tiene como objetivo identificar las fortalezas y debilidades del sistema de la perspectiva del franquiciado. Este estudio les permitirá a los franquiciadores identificar áreas en las que los franquiciados están menos satisfechos. Si los franquiciados están satisfechos con numerosos aspectos que influyen en la relación franquiciador-franquiciado, el último puede tener un alto grado de lealtad para con sus franquiciadores y esto beneficiaría a la red como un todo. Este artículo usa la variante del modelo clásico de importancia-performance de Martilla y James (1977) y otros (Ábalo, Varela, y Rial, 2006; Picón, Varela y Braña, 2011). Los resultados demuestran que los atributos con los que los franquiciados de agencias de viajes están más insatisfechos son: publicidad en cadena, apoyo continuo de los franquiciadores, el apoyo inicial del franquiciador, entrega de los franquiciadores y capacitación dada por los franquiciadores.

PALABRAS CLAVES / Satisfacción, análisis importancia-performance, franquicia, ramo de agencias de viajes, atributos.

\section{jmramhur@upo.es}

Professor at Universidad Pablo de

Olavide, Departamento de Economía, Métodos Cuantitativos e Historia Económica - Sevilla, Spain 


\section{INTRODUCTION}

Although a considerable variety of business alliances types exist, franchising has emerged as a powerful form of two-party collaboration (Brookes \& Altinay, 2011). Both the franchisor and franchisee have substantial incentives to enter a franchising system. Literature in this field shows franchisors choose franchising as a business model because it enables them to grow faster in comparison to other business models. It may be because franchisees supply human and financial capital to carry out the expansion (Bercovtiz, 1999; Elango \& Fried, 1997; Emerson, 1998; Justis \& Judd, 2002; Lim \& Frazer, 2004; among others).

On the other hand, franchisees choose franchising due to the help supplied by franchisors (Justis \& Judd, 2002). Many entrepreneurs do not have previous work experience to be successful businessmen; therefore, they prefer appealing to franchisors to receive help and training to start their own business (Lim \& Frazer, 2004). Consequently, franchisors need to be responsive and attend franchisees' needs, particularly during the early stages of the partnership (Altinay, Brookes, Yeung, \& Aktas, 2014).

Prior to the contractual relationship between the franchisor and franchisee, franchisors direct their potential franchisees towards ideal business locations and help them with the interior designing and material procurement. They also support franchisees in recruiting ideal employees, while some offer business management training, operation manuals, marketing assistance, etc. (Justis \& Judd, 2002; Kaufmann \& Stanworth, 1995; Lim \& Frazer, 2004; Williamson, 1995; among others). Likewise, a franchisee receiving satisfactory support from the franchisor partner develops confidence in the franchisor's capabilities (Altinay \& Brookes, 2012; Flint-Hartle \& de Bruin, 2011; Hing, 1995). Therefore, the relationship between the franchisor and franchisee is of vital importance for the development and success of a franchise.

However, franchisees are not always satisfied with the affiliation, believing they do not receive enough assistance or resources, not only at the beginning, but also at the development stage. Moreover, franchisees gradually learn the franchisor's operating methods, strategies, and their strengths and weaknesses. As franchisees' success increases, they attribute the success to their own efforts and business qualities rather than their franchisor (Davies, Lassar, Manolis, Prince, \& Winsor, 2011). In franchising, while franchisors seek to maintain uniformity in their standard operations to preserve the integrity of the brand, the franchisees often wish to have greater autonomy in operation (Sorenson \& Sørensen, 2001; Weavin \& Frazer, 2007).

These issues create tension in the relationship. Indeed, the franchisees begin to doubt the contract's suitability and start to feel dissatisfied. Dissatisfaction can lead to conflicts and negative results. This ultimately affects the franchisor, whose profitability depends on the success of the franchisees (Harmon \& Griffiths, 2008). This is why studying franchisees' satisfaction level provides useful information for franchisors and for determining the relationship success in the chain. This study focuses on the travel agency industry.

Researchers recognize the need to create a collaborative and cooperative atmosphere to handle tensions (Altinay \& Brookes, 2012). Franchisors should identify areas or factors franchisees are dissatisfied with, and areas they are not to deal with these tensions. They should also gauge the degree of satisfaction in different areas. Such analysis would enable franchisors to maintain their efforts and relationship in satisfaction areas and improve in dissatisfaction areas. Franchisors must also try to rank factors their franchisees are dissatisfied with, as the degree of dissatisfaction may vary with factors.

This study contributes to the limited literature on travel agency franchisees' satisfaction levels. Its aim is to measure satisfaction within the current arrangement of franchising. It analyzes the franchisees' perceptions relating to the franchisor's effort, thus measuring the perceived experience. Specifically, the study aims to identify strengths and weaknesses of the system from the franchisee's point of view. In order to achieve this goal and bridge the literature gap, this study analyzes the attributes affecting satisfaction.

The study's justification is that it serves as a tool for improving the weaknesses of the franchising system and identifying the strengths. Franchise brands must engage in selfcriticism regarding such weaknesses and try to address them within their own franchises, while maintaining efforts related to strengths.

The methodology used here to meet the objectives is importance-performance analysis (IPA). The study uses a variant of the classic importance-performance model of Martilla and James (1977) and others (Ábalo et al., 2006; Picón et al., 2011). The data have been obtained via a questionnaire sent to travel agency franchisees operating in Spain. This sector is highly representative of franchising arrangements. It is dynamic; franchises have been forced to renovate or merge to continue to exist. With the backdrop of the financial crisis prevailing in recent years, the travel agency sector in Spain, in particular, reflects the current situation of Spanish franchising to a great extent.

This remainder of this paper is organized as follows. The literature review section examines motives for potential franchisees to join a franchise. The franchisee's satisfaction is also briefly covered in this section. Following the literature review, the author will develop and expound the methodology, which is 
based on the standard IPA format. The results are then presented in a summary. The final section of the paper highlights managerial implications of the findings, and sets out areas for future research.

\section{LITERATURE REVIEW}

Franchising systems have attracted growing interest among researchers due to their increasing importance as a mechanism of business growth (Baena, 2010). Over the years, the number of published works about the franchising system has grown considerably, mostly in North American and British literature due to the greater implementation of this system in these areas than in other countries (Jones, 2003).

Different lines of enquiry have been discoursed over the years. Elango and Fried (1997) analyzed extensively the previously published franchising studies. According to their work, franchising literature can be divided into three trends: franchising and society, franchising relationship creation, and franchise operations. Forward and Fulop (1997) also reviewed different theoretical perspectives from researchers. In their view, three main issues have attracted academic attention: (a) the value of franchising for franchisees; (b) the contractual effects on control, conflict, balance of power, and franchisee autonomy; and (c) the management of conflicting strategies. Combs, Michael, and Castrogiovanni (2004) also reviewed different theories supporting franchising, showing that resource scarcity and agency theory are the most discussed topics in explaining how the franchising system functions. These authors show evidence of three other theories that influence franchising: the upper echelons theory, resource-based theory, and the institutional theory. Furthermore, the signaling theory is also adequate to study franchised networks (Dant \& Kaufmann, 2003; Gallini \& Lutz, 1992).

Baena (2010) reviews research lines in the franchising system from the 1960 s to 2009 . She believes that there are two main theoretical approaches in franchising - agency theory and resource scarcity theory, although there are secondary theories. In this study, four main research lines are shown: 1) social reasons of franchising; 2) expansion of franchising; 3) characteristics of the franchisor and the franchisee; and 4) franchisor-franchisee relations.

The researchers who have used these theories and other research fields have made tremendous progress in explaining and describing the franchising system (Combs et al., 2004). However, despite the increase in and diversity of articles about franchising, most of the literature has used the franchisor's perspective (Altinay, Brookes, \& Aktas, 2013; Brookes \& Altinay, 2011; Hing, 1995; Kaufmann \& Stanworth, 1995). The reason is that the ultimate decision about franchising rests with the franchisor (Kaufmann \& Stanworth, 1995), as does the final decision about incorporating a franchisee.

Research on franchising from the franchisor's point of view is broad and varied. Studies have analyzed social reasons for franchising, expansion of franchisor, the internationalization of franchising, the selection methods for choosing franchisees, the characteristics of franchisors, and the relationships between franchisors and franchisees (Baena, 2010).

Nevertheless, from the franchisee's point of view, the analyses have basically been about the characteristics of franchisees, the selection of a franchisor, and the reasons for joining a franchising network (Bradach \& Kaufmann, 1988; Brookes \& Altinay, 2011; Kaufmann \& Stanworth, 1995; Peterson \& Dant, 1990; Ramírez, Rondán, Guerrero, \& Berbel, 2011; J. Stanworth, Stanworth, Granger, \& Blyth, 1989; J. Stanworth \& Purdy, 1994; among others). There is therefore an important research gap in this area.

The franchisee is a key element within the franchising system. However, they must have a series of important characteristics to be able to develop their work within the system. The franchising system can be more appropriate for some franchisees than for others (Ramírez et al., 2011). Indeed, some franchisees that enter the franchising system make a greater contribution to the success of the relationship than others that fail (Jambulingam \& Nevin, 1999).

Incorporating an entity into a franchising system depends on both the motivation of the franchisee, and the motivation pushing the franchisor. From the point of view of the franchisee, in choosing the franchisor, certain requirements have to be analyzed such as the investment required, contractual conditions, franchisor's profitability, reputation of the trademark, evolution of the number of franchisees, its training program, and market available. Tatham, Douglas, and Bush (1972) were among the first to thoroughly analyze these characteristics. Since then, other studies have analyzed the different requirements to be met to have a successful relationship with the franchisor (Brookes \& Altinay, 2011; Clarkin \& Swavely, 2006; Edens, Self, \& Grider, 1976; Forward \& Fulop, 1997; Jambulingam \& Nevin, 1999; Knight, 1986; Ramírez et al., 2011; among others).

The role of the franchisor (brand reputation, marketing, training and assistance) contributes to the relationship development through the creation of trust, and demonstration of commitment, both at the pre and post stages of franchising partnerships (Altinay et al., 2014).

Previous studies have examined advantages of franchising with respect to other organizational forms. Litz and Stewart (1998) showed that franchising brands are a source of strategic 
advantage, because firm outcomes are positively impacted. Kaufmann (1999) shows the rationale behind the franchisee's decision to acquire a franchise. It depends on industrial factors such as growth, competitiveness, and experience; organizational factors such as personality traits; and financial factors, business factors, and brand aspects such as the franchisor's reputation, terms of the contract, cost, growth of the system, and power of the brand.

According to Kaufmann (1999), some advantages associated with being a franchisee, such as independence and personal involvement in a firm, are valued in the same way as in an independent business. Notwithstanding, obtaining personal benefits is an important advantage of franchising in contrast to other forms of business.

Previous literature paid close attention to the motives that lead a business to become a franchisee. Ramírez and Quattrociocchi (2009) reviewed the main papers about franchisees' motivation for accessing a franchising system. They state that the ranking of motives varies from study to study, and thus between countries. Therefore, the motivation is not as homogeneous as expected by practitioners and researchers (Peterson \& Dant, 1990).

Exhibit 1 shows the main results from previous studies. Guilloux, Gauzente, Kalika, and Dubost (2004) found that the main franchisee motivation in France is advertising and start-up support. Potential franchisees need to be assured particularly about the initial support provided by the franchisor. Trade name association and the possibility for development are the second-most popular motives for individuals to enter franchising. Although their methodological approaches are not the same as those used in previous studies, these two motives are widely used in the literature. Withane (1991) reports that the proven business format is the main motive in Canada. Many prospective franchisees choose to join franchises rather than start an independent business in order to take advantage of the established business format, brand goodwill, and initial and ongoing customer support. This shows the importance of support as a motivational incentive for companies to enter franchising. Peterson and Dant (1990) found that the main motives in the United States are "training provisions," "greater independence," and "established name." "Lower operating costs," and "less management involvement" were rejected as advantages. Knight (1986) found that in Canada and in the United States, the main motive was the already established commercial name; the second ranked motivation was a greater job satisfaction compared to salaried employment. J. Stanworth (1985) describes that the main motive was "national affiliation," which, according to Peterson and Dant (1990), can be considered equivalent to "established name." Finally, Hough (1986) found that the main motive was ongoing support. Thus, the main criterion varies with country and time.

\section{Exhibit 1. Comparison of previous empirical studies}

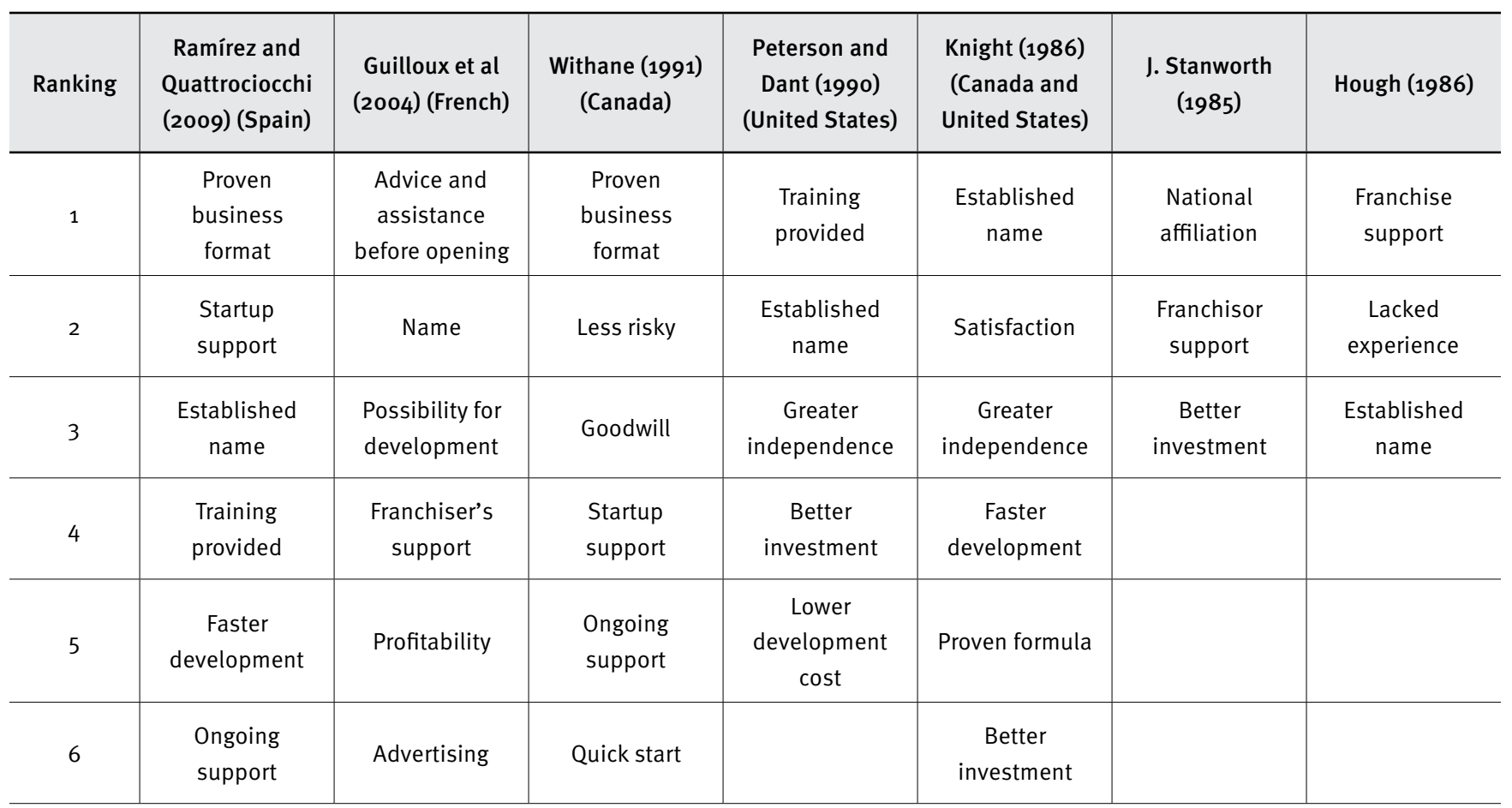

Source: Ramírez and Quattrociocchi (2009) based on Guilloux et al. (2004) and Peterson and Dant (1990). 
The previous motives, along with others, form part of the studies carried out by both researchers and consultants. Some of these motives relate strongly to franchisees' satisfaction, which determines the relationship between the franchisor and franchisee. Satisfaction is a key element for remaining in the system, and thus contributing to the long-term survival of the franchising agreement (Gauzente, 2003). There is an important theoretical support for franchisors' interest in the franchisees' wellbeing and satisfaction (Roh \& Yoon, 2009). The repercussions of the franchisee's satisfaction are evident, and have been previously investigated. Hing (1995) showed the importance of satisfaction and its relation to franchisees recommending new candidates. The same study also showed the relation between satisfaction, and choosing to open new locations under the same franchise.

The literature identifies three main approaches when evaluating the franchisee's satisfaction (Gauzente, 2003):

- The first considers franchisee's satisfaction as a member of the channel. Franchisees are treated as the franchisor's customers (Berndt, 2009). Satisfaction is related to the running of the channel and the relationships within it. Therefore, the dimension of satisfaction is described over time (longitudinal) instead of at a specific moment (Viera \& Slongo, 2007).

- The second considers the franchisee as an employee (Morrison, 1997). The franchisee is likewise considered as a purchaser after having initiated the franchisorfranchisee relationship. The franchisee's satisfaction is related to job satisfaction.

- Finally, a third approach analyzes franchisees' satisfaction based on the activities and tasks carried out in their outlet (Hing, 1995). This approach refers to the difference between what a person earns and what this person thinks they should earn. That is to say, it measures whether the employees or franchisees are satisfied with their jobs (Viera \& Slongo, 2007).

Morrison (1997) showed the importance of satisfaction is related to franchisees' activity in their unit, organizational involvement and relationships with the system and franchisor, and the intention to remain in the system.

It is important to show that when franchisees are satisfied with their franchisor, they are more cooperative and contribute to the franchise system (Roh \& Yoon, 2009).

Satisfaction is closely linked to the relationships that develop between the franchisor and franchisee. In this sense, relational marketing is especially important, as the basic concept is the relationship rather than the exchanges within the relationship suggested by transactional marketing. Those franchisors who contribute real value to their franchisees based on stable and profitable relations over time will survive.

Franchisees enter the franchising system for a variety of reasons, and consequently can show different levels of satisfaction. It is therefore of vital importance to know which are the most important factors for franchisees, and what value franchisees give to these factors.

The present study aims to present information about how this system of association works from the franchisee's perspective. Specifically, this study seeks to measure franchisee's satisfaction in regards to the functions they carry out within their franchise. Therefore, it encompasses aspects of the first and third approach identified in the literature review.

In order to complete this assessment, the IPA model was utilized. The IPA model identifies which product or service attributes should be the focus to enhance customer satisfaction (Matzler, Bailom, Hinterhuber, Renzl, \& Pichler, 2004). Although the IPA model is relevant as an instrument to measure satisfaction, there is still a lack of empirical application to franchisee's satisfaction. In the context of franchising, the IPA model guides the prioritization and development of action plans to minimize mismatches between importance and performance, resulting in an improved deployment of franchisor resources.

\section{METHODOLOGY}

\section{Sample}

The data were obtained from a sample of 65 franchisees within the travel agency sector in Spain. Since there is no register of franchisee establishments in Spain, getting the data was quite complex and laborious.

The travel agency industry is one of the most representative sectors of the franchising system in Spain. Indeed, according to Tormo Franchise Consulting (2014), the 21 travel agency franchises that operated in Spain in $2014 \mathrm{had}$ 3,454 franchisee establishments. It is the third largest industry sector in terms of number of franchisee establishments. Moreover, this sector billed 1,095 million euros, generating 11,180 direct jobs.

The characteristics of the hospitality industry are: large mobility volume, wide geographic distribution, customers searching for a familiar product, and unique travel expectations. Franchising is thus an appropriate method for expansion in this industry (Pine, Hanqin, \& Qi, 2000).

Moreover, the travel agency sector is dynamic. Many trademark brands have been forced to rethink their service, or 
to merge with others to overcome economic cycles. Despite this, a great number of new business models are concentrated here and the number of new entrants is expected to grow more in the near future due to the lower initial investment (Tormo Franchise Consulting, 2014). Therefore, it is a highly representative sector of the franchising system in Spain.

A brief questionnaire was sent out to travel agency franchisees operating in Spain. Franchisees had to score importance and performance of attributes on a scale. The scale ranged from o to 10 points, where o represents the lowest value, and 10 represents the highest.

Usually, franchisors are reluctant to provide e-mail addresses of their franchisees. However, e-mails addresses were obtained through an arduous internet search and franchisees were mailed the request to participate in the study. These e-mails included a letter of presentation and an electronic link to access the questionnaire online. The questionnaire was also sent by post in order to increase the response rate. A total of 354 franchisees were contacted and 65 duly filled out questionnaires, representing an $18.36 \%$ response rate.

\section{Attributes}

The IPA model identifies areas to which marketing resources should be allocated in order to improve and enhance the quality of the relationship. In this case, all the attributes are controlled by the franchisor.

Literature regarding incentives for entering franchising mentions many factors, but some of them are not directly controlled by the franchisor. For example, outlet profitability and location are not controlled by the franchisor. The profitability of a franchisee depends on several factors: brand strength, location, management, the growth of the particular industry, and so on. Location is another factor many franchisors do not control. While they expect the franchisee to have a general area in mind, including factors such as the parking space, foot traffic, status of the neighboring areas, and price, the final decision is taken by the franchisee.

Based on the above comments, only attributes controlled by the franchisor and directly influencing franchisee satisfaction have been used in this study.

The literature on franchisees' satisfaction provided the attributes to measure satisfaction (Barbadillo \& Associates, 2013; Berndt, 2009; Guilloux et al., 2004; Harmon \& Griffiths, 2008; Hough, 1986; Knight, 1986; Peterson \& Dant, 1990; Ramírez \& Quattrociocchi, 2007; Roh \& Yoon, 2009; J. Stanworth, 1985; Withane, 1991). Exhibit 2 shows the attributes selected.
Exhibit 2. Attributes selected to measure satisfaction

\begin{tabular}{c|l}
\hline 1 & Brand image \\
\hline 2 & Business tried before \\
\hline 3 & Size of the franchise \\
\hline 4 & Experience of the firm \\
\hline 5 & Experience of the chain \\
\hline 6 & Belonging to the Official Registry of Franchisors \\
\hline 7 & Training provided by the franchisor \\
\hline 8 & Initial investment \\
\hline 10 & Initial support of the franchisor \\
\hline 11 & Ongoing support of the franchisor \\
\hline 12 & Chain advertising \\
\hline 13 & Initial fee \\
\hline 14 & Royalties \\
\hline 15 & Advertising fee \\
\hline 16 & Delivery from the franchisor \\
\hline 17 & Supervision by the franchisor's head office \\
\hline 18 & Internationalization of the franchise \\
\hline 12
\end{tabular}

All of the attributes included in the satisfaction assessment can be actively modified by the franchisor. The goal of this work is to identify the attributes that franchisors must focus on to prevent failing in elements considered important by franchisees and to reallocate resources from areas of little importance. Franchisors would know which attributes must be improved to increase franchisees' satisfaction. It does not make sense to include any attribute that the franchisor cannot control as it cannot be used to modify performance.

\section{Importance-Performance Analysis (IPA)}

The methodology is based on the traditional IPA method from Martilla and James (1977). One of the model's limitations is that the action grid establishes arbitrary axes for the variables, which may mislead management. In this study, the data has been analyzed by means of a new graphic display to address the discrepancies (Ábalo et al., 2006; Picón et al., 2011; Sethna, 1982). This method is likely to be more useful to managers for formulating strategic actions.

IPA users consider the importance of the different attributes of a product or service and their rating of its performance once they have used it.

The traditional multi-attribute and expectation-value models maintain that each product or service is made up of a series of independent attributes. That means the valuations of the consumers are made from the weighted aggregation of each 
of these attributes' evaluations (Fishbein, 1967). This is reflected in the following expression (Fishbein \& Ajzen, 1975):

$$
V_{0}=\sum_{i=1}^{n} I_{i} \cdot V_{i}
$$

where $V_{o}$ is the global valuation of the product or service, $V_{i}$ is the importance that each attribute has for the subjects, $V_{i}$ is the valuation that each attribute receives, and $n$ is the total number of attributes that configure the product or service.

Past research has shown that not all attributes explain the global satisfaction with a product or service in the same way (Picón et al., 2011). Consumers tend to make valuations based on a limited number of characteristics; therefore, the most important attributes largely affect their evaluation, while the least important hardly have any influence. This is why weighting valuations is important.

Unlike the multi-attribute models of Fishbein (1967), in which the importance and valuation are analyzed in an aggregated manner, in the IPA model, importance and valuation are analyzed separately. This is significant because a high score can be obtained via high importance and low performance or via low importance and high performance (Ennew, Reed, \& Binks, 1993).

The classic representation of the IPA model was proposed by Martilla and James (1977) by means of a two-dimensional grid, where the values of importance and performance are plotted in four quadrants (Figure 1).

Figure 1. Classic representation of importanceperformance analysis (Martilla \& James, 1977)

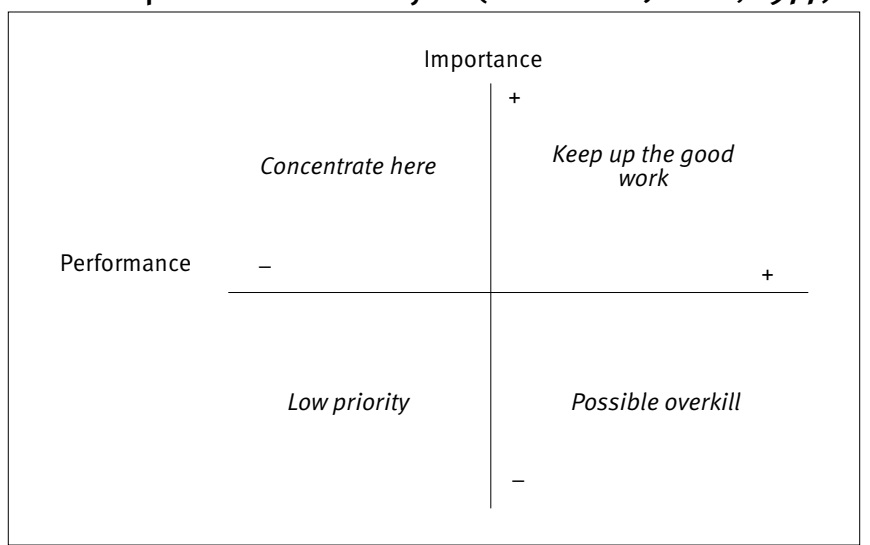

Concerning policy direction, a distinction can be made between areas in need of further effort (A: high importance-low performance), areas in which too much effort is being expended (D: low importance-high performance), and those in which the current effort is appropriate (B: high importance-high performance and C: low importance-low performance). Employing such analyses could enable management to allocate resources more efficiently, in particular to the quadrant A factors. The marketing strategy to be followed should be defined based on the quadrants where the attributes fall.

Although the IPA model offers simple and direct implications for subsequent marketing actions and it can be applied in many diverse disciplines, it has its weaknesses, such as the axes' positioning and the measurement of the attributes' importance (Picón et al., 2011). In order to avoid these problems, Picón et al. (2011) proposed a new way of representing results graphically. They did this by considering the analysis of discrepancies, meaning the differences between the importance and performance. This is meant to address arbitrariness, which exists when positioning the axes, as well as increase the amount of information provided by the representation of the quadrants.

\section{RESULTS}

The average scores of importance and performance for each of the 20 attributes are shown in Table 1.

All of the scores of importance are greater than the scores of performance. Consequently, in principle, all of the attributes are open to improvement. Nevertheless, according to the classic representation of Martilla and James (1977), which appears in Figure 2, the majority of the attributes fall in the quadrant "keep up the good work," except four attributes which fall in the quadrant "concentrate here." According to this figure, only four areas present any deficiencies.

This first representation has a clear bias, as the difference of average scores between importance and performance indicate deficiency in all attributes, while the graph shows only four attributes are deficient. As Ábalo et al. (2006) pointed out, it is necessary to plan a modification of the graph for the representation to be more coherent and realistic.

A first transformation, already noted by Martilla and James (1977), and later Ábalo et al. (2006), consists of modifying the scale of the axes. These authors propose placing the beginning of the axes according to the smallest value obtained in the average scores. Yet, in different studies by these authors, the end of each axis has not been modified. With the aim of making a coherent and equitable transformation, in this study, we propose to also modify the end of the axes according to the highest value obtained. It is justified because the range of the axes is reduced, and consequently the relative distances of the attributes will 
increase. Hence, the new graphical representation would start its axes on value 4, the end point being value 9. Consequently, the average score of the new scale will be 6.5. Figure 3 shows the new graphical representation.

Table 1. Importance, performance and discrepancies of attributes

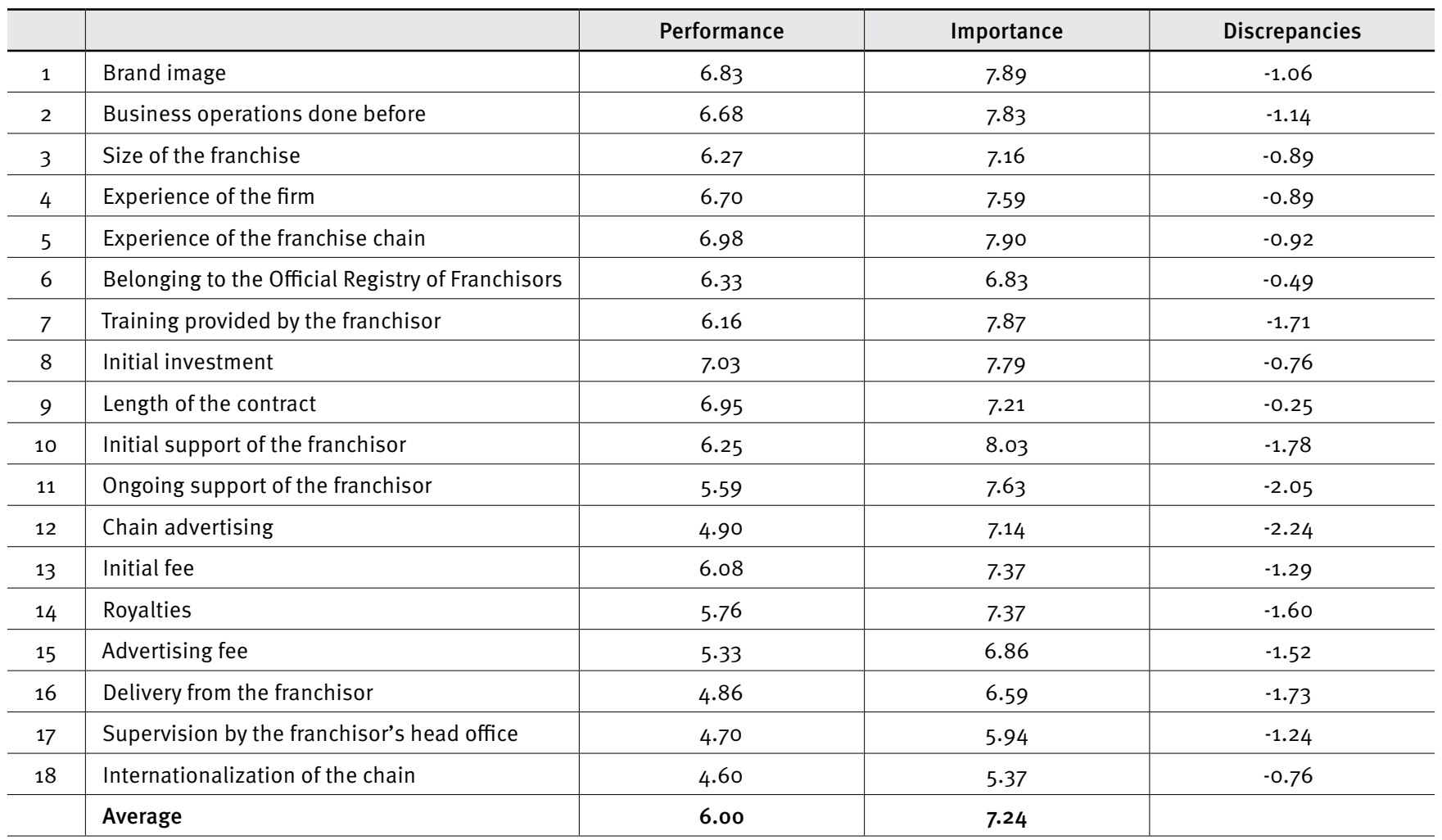

Figure 2. Results based on classic representation of importance-performance analysis

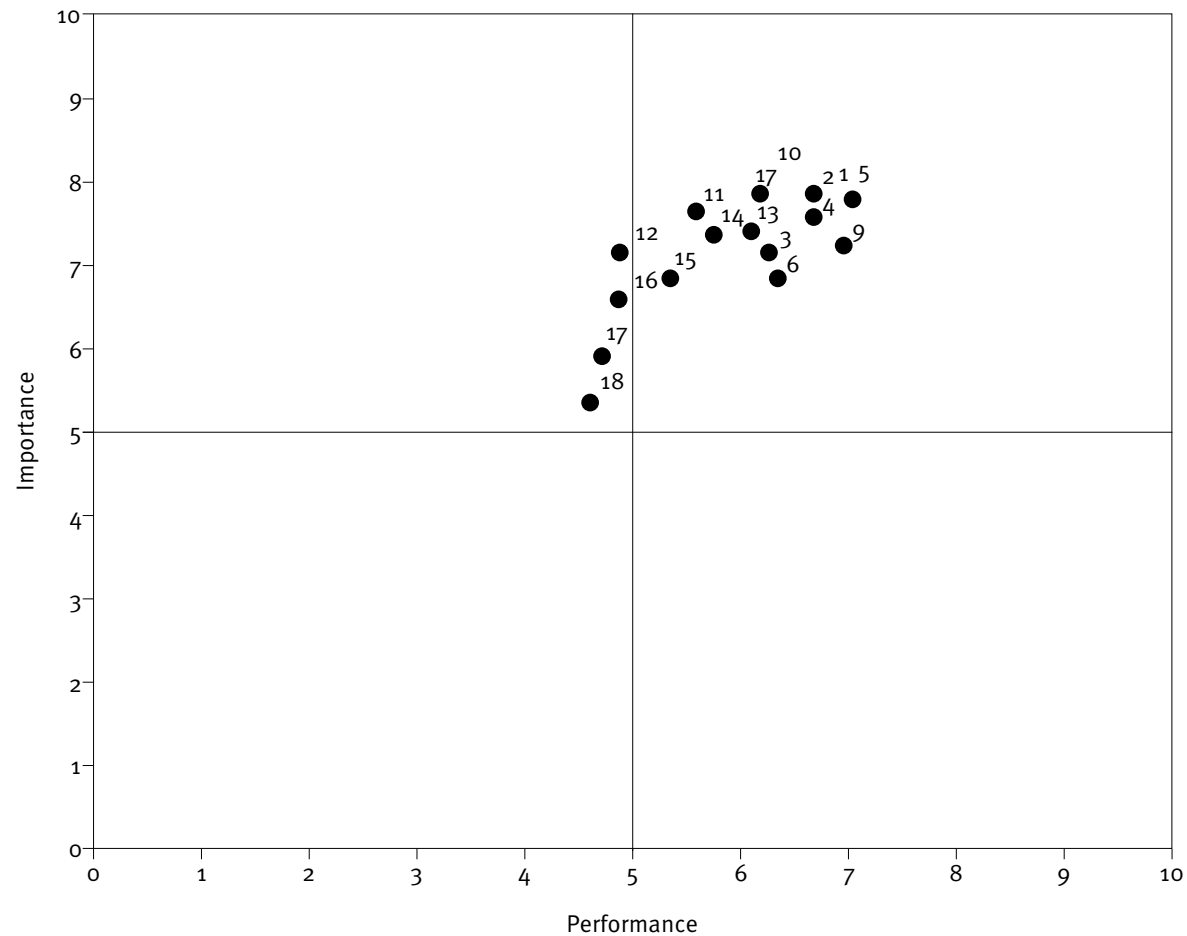


Figure 3. Classic representation with the new scale

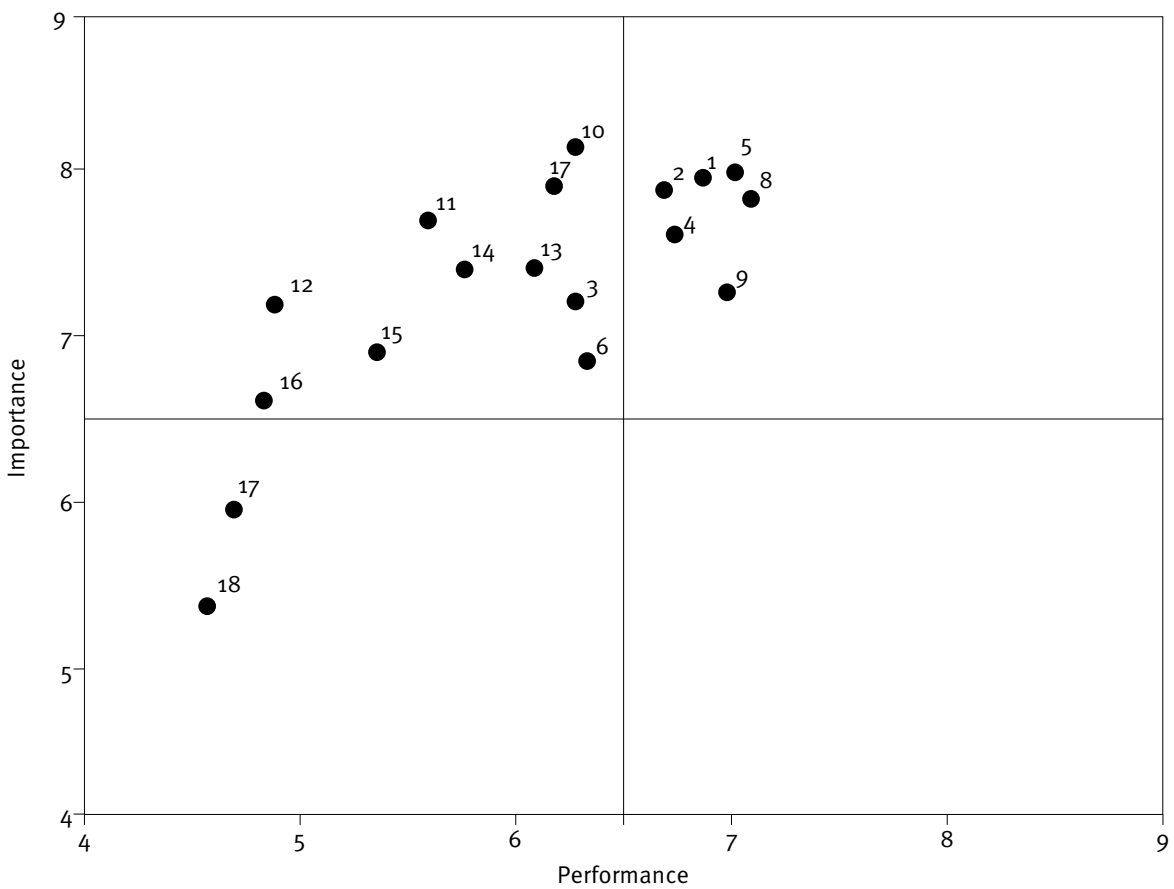

In Figure 3, the number of attributes that fall in the quadrant "concentrate here" has increased notably. This representation is closer to reality given that the number of attributes open to improvement has increased, as the differences between performance and importance reflect. However, in this representation, there is still a considerable number of attributes in the quadrant "keep up the good work"; hence, contradictory evidence persists.
According to Ábalo et al. (2006), another approach that has been followed in literature by some authors (Alberty \& Mihalik, 1989; Guadagnolo, 1985; Hollenhorst, Olson, \& Fortney, 1992; Martilla \& James, 1977) consists of placing the measurement axes in their respective average dimensions. Inasmuch, we obtained a more or less equitable representation of the attributes between the four quadrants (Figure 4).

Figure 4. Graphic with axes in average performance (6.00) and average importance (7.24)

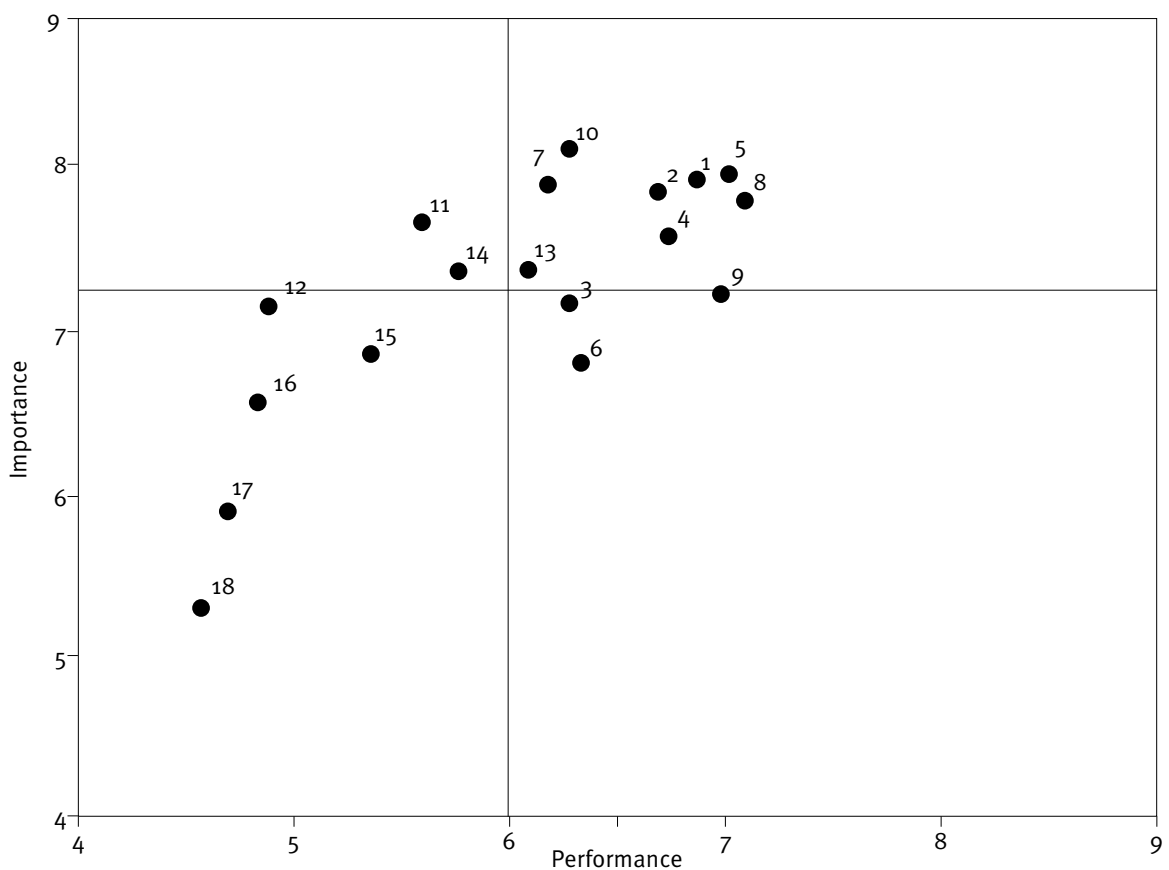


However, even though this representation distributes the points between the four quadrants more or less equitably, it is considered to be a partially artificial representation of strengths and weaknesses (Ábalo et al., 2006). Likewise, according to differences between performances and importance, all of the averages are open to improvement. Thus, the information supplied by the graphical representation is also contradictory.

Attempting to solve the problems mentioned, the literature has tried to combine models based on different representations in the quadrants (classic models) and the so-called "diagonal models." The diagonal models divide the importance-performance analysis space into two halves (Ábalo et al., 2006; Hawes \& Rao, 1985; Nale, Rauch, Wathen, \& Barr, 2000; Picón et al., 2011; Sampson \& Showalter, 1999; Slack, 1994).

Diagonal models are based on the calculation of discrepancies, defined as the differences in scores between performance and importance. Those attributes with low discrepancies are the ones where importance exceeds the performance, hence representing high priorities for improvement. In this type of model, a $45^{\circ}$ diagonal is represented in the graph such that points placed above the diagonal have negative discrepancies and are therefore open to improvement. The greater the distance from the diagonal, the greater the priority of management concentrating on it. The classic and diagonal models are combined in Figure 5.

The first feature that can be deduced from the graph is that all of the points fall above the diagonal, so all the attributes are open to improvement.

Within the attributes that fall in the quadrant "concentrate here," those which are of higher priority are found more distant from the diagonal. They are the attributes chain advertisement, ongoing support of the franchisor, initial support of the franchisor, delivery from the franchisor and training provided by the franchisor. The lower-priority attributes are length of the contract and belonging to the Official Registry of Franchisors.

Figure 5. Representation of classic model and diagonal model

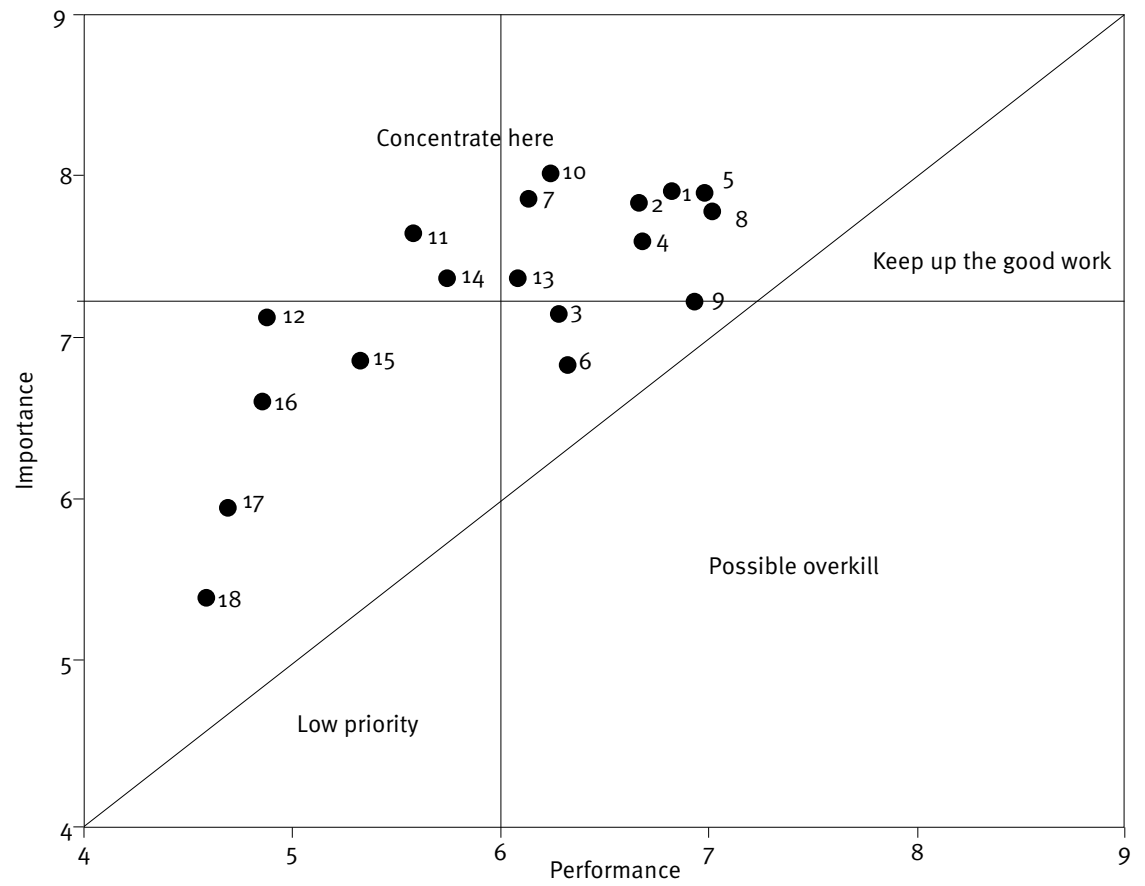

\section{DISCUSSION AND MANAGERIAL IMPLICATIONS}

The key objective of the IPA model is to facilitate the identification of attributes from the franchisor-franchisee relationship for which, given their importance, the franchisor underperforms or overperforms.
This study provides valuable information for franchisors in the travel agency industry. It is beneficial because travel agency franchisees' satisfaction values enable franchisors to identify problem areas and improve the network's functioning. If franchisees are satisfied in a great number of aspects, they may have a high degree of loyalty towards the franchisors. This is beneficial for the network. Franchisors expect franchisees to 
support and promote the trademark names in order to guarantee the brand's continued existence (Shivell \& Banning, 1995).

From the point of view of franchisees, this study diagnoses the satisfaction level of them, and thus helps potential franchisees decide whether to join the network.

Two important findings can be described in this study. First, all the attributes regarding the franchisor-franchisee relationship in the travel agency industry are open to improvement. Second, the priorities from attributes improvement vary from one attribute to another.

The attributes with highest priority must be dealt in first place. The attributes, in order of their ranking, are as follows: 1 ) chain advertising, 2) ongoing support of the franchisor, 3) initial support of the franchisor, 4) delivery from the franchisor and 5) training provided by the franchisor. The attributes with lowest priority are: 1) length of the contract, 2 ) belonging to the Official Registry of Franchisors, 3) Internationalization of the franchise, 4) size of the franchise and 5) experience of the firm.

The attribute that travel agency franchisees feel most dissatisfied with is chain advertising. This study was carried out using data from travel agencies. This industry sector is highly competitive, not only between establishments that operate under the franchising system, but also among establishments that operate under other business forms. In this highly competitive environment, chain advertising is very important. Managing this aspect well is fundamental for travel agencies to reach their customers. On the other hand, chain advertising is currently not only carried out through traditional channels, but also through new electronic channels. Therefore, franchisors, especially in this sector, should center their efforts on improving their advertising features.

The second attribute that franchisees are most dissatisfied with is the ongoing support of the franchisors. This is one of the main reasons why franchisees choose franchising (Guilloux et al., 2004; Hough, 1986; Ramírez \& Quattrociocchi, 2009; J. Stanworth, 1985; Withane, 1991). A franchise requires, among other things, the franchisor's experience and expertise in order to work. These terms do not only refer to technical knowledge, but can also be broadened to include franchisors' commercial, logistic, administrative, and accounting experience. Thus, given the importance of knowledge transfer, ongoing support to franchisees is essential. The results of this study show a serious deficiency in this attribute, which may convey a need for it to be analyzed by franchisors to improve performance.

The third attribute that franchisees are most dissatisfied with is the initial support from the franchisors. If it is important for franchisees to have ongoing support, it is more so at the beginning of the relationship. Common initial support services involve the joint planning of the startup process; the analysis of the target market; determining an ideal location; establishing a commercial area of exclusivity; feasibility of the business project; furnishing equipment and decoration; supervising the fitting-out of the premises; estimating the necessary initial investments and seeking financing; collaborating in the choice of personnel; assessing the initial opening stock; conducting the initial training of franchisees and their personnel; providing operational and image manuals; planning a launch campaign in the market of territorial exclusiveness; elaborating reports of planned exploitation; and providing technical and commercial assistance (Alonso, 2003; Benavides, Mingueta, \& López, 2008). The results of the present study show that franchisees are notably dissatisfied with the initial support of the franchisor.

Delivery from the franchisor and training provided by the franchisor are the fourth and fifth attributes with which franchisees show a high degree of dissatisfaction. These aspects are to a certain extent related to the initial and ongoing help of the franchisor, so they must be prioritized. Moreover, it must be noted that, in franchising, growth is very important because it depends on how franchisors use their scarce resources to train potential franchisees (Bordonaba-Juste, Lucia-Palacios, \& PoloRedondo, 2011).

Attributes causing less dissatisfaction are length of contract, belonging to the Official Registry of Franchisors and internationalization of the franchise. According to online information and specialized magazines, contract length tends to be short (from one to five years), and is hence, not a cause of concern for franchisees. Franchisees are, however, concerned about their franchisor belonging to an Official Registry of Franchisors. Being a registered member is a sign of trust and security (Calderón Monge \& Huerta Zavala,, 2015). However, it appears to be much less important than expected in Spain, even though section 2 of article 62 in the January 15 7/1996 Law, which regulates the retail trade, requires franchisors to furnish data to the Official Registry of Franchisors. Baena and Cerviño (2010) show that internationalization helps improve the image of the chain brand. In general, franchisees prefer renowned trademarks. Although in some cases, a high degree of internationalization may lead to less emphasis on domestic expansion, thus implying lower ongoing support, franchisees do not feel dissatisfied with the internationalization. Finally, the priority for other attributes falls between that for the abovementioned groups.

\section{CONCLUSION}

In conclusion, the difference between performance and importance in the attributes shows different levels of dissatisfaction. 
Franchisors must improve all aspects analyzed, but in particular they must pay special attention to improving franchise advertising, and customer support at initial and ongoing stages.

A limitation of this work is the non-randomized sampling method used, which limits the generalizability of the results. Furthermore, a small sample was used owing to the difficulties of obtaining data; a higher sample size is more appropriate. Regarding future research recommendations, the current study could be expanded to other franchising sectors and countries to obtain a more comprehensive view and identify any differences.

\section{REFERENCES}

Ábalo, J., Varela, J., \& Rial, A. (2006). El análisis de ImportanciaValoración aplicado a la gestión de servicios. Psicothema, 18(4), 730-737.

Alberty, S., \& Mihalik, B. (1989). The use of importance-performance analysis as an evaluative technique in adult education. Evaluation Review, 13(1), 33-44. doi:10.1177/0193841X8901300103

Alonso, M. (2003). La Franquicia de la A a la Z: Manual para el franquiciador y el franquiciado. Madrid: Editorial Lid. S. L.

Altinay, L., \& Brookes, M. (2012). Factors influencing relationship development in franchise partnerships. Journal of Services Marketing, 26(4), 278-292. doi:10.1108/08876041211237578

Altinay, L., Brookes, M., \& Aktas, G. (2013). Selecting franchise partners: Tourism franchisee approaches, processes and criteria. Tourism Management, 37, 176-185. doi:10.1016/j.tourman.2013.01.016

Altinay, L., Brookes, M., Yeung, R., \& Aktas, G. (2014). Franchisees' perceptions of relationship development in franchise partnerships. Journal of Services Marketing, 28(6), 509-519. doi:10.1108/JSM-092013-0240

Baena, V. (2010). Teorías y líneas de investigación en el sistema de la franquicia: Una revisión desde los años 60 hasta 2009. Cuadernos de Gestión, 10(2), 43-66. doi:10.5295/cdg.100155vb

Baena, V., \& Cerviño, J. (2010). Selección de mercados en la expansión internacional de la franquicia española. Información Comercial Española. Revista de Economía, (857), 183-200.

Barbadillo \& Associates (2013). Primer estudio de satisfacción del franquiciado. Retrieved from www.bya.es

Benavides, M. C., Mingueta, B., \& López, J. I. (2008). Transferencia de conocimiento en la creación y el funcionamiento de los sistemas de franquicia. Un estudio empírico. Economía Industrial, 368, 227-237.

Berndt, A. D. (2009). Franchisee satisfaction among food franchisees: An exploratory study. Southern African Business Review, 13(1), 1-20.

Bercovitz, J. E. L. (1999). An analysis of the contract provisions in business-format franchise agreements. In J. Stanworth \& D. Purdy (Eds.), Proceedings of the 13th Conference of the International Society of Franchising, 1-50.

Bordonaba-Juste, V., Lucia-Palacios, L., \& Polo-Redondo, Y. (2011). An analysis of franchisor failure risk: Evidence from Spain. Journal of Business \& Industrial Marketing, 26(6), 407-420. doi:10.1108/08858621111156403
Bradach, J., \& Kaufmann, P. (1988). Franchisee or independent business person: Some observations on the decision process. In G. E. Hills \& W. Laforgue (Eds.), Research Marketing-Entrepreneurship Interface (pp. 38-48). Chicago: University of Illinois.

Brookes, M., \& Altinay, L. (2011). Franchise partner selection: Perspectives of franchisors and franchisees. Journal of Services Marketing, 25(5), 336-348. doi:10.1108/08876041111149694

Calderón Monge, M. E., \& Huerta Zavala, P. A. (2015). Ingresos netos del franquiciado: Una señal para elegir una franquicia en una crisis. RAERevista de Administração de Empresas, 55(6), 688-698. doi:10.159o/ So034-759020150607

Clarkin, J. E., \& Swavely, S. M. (2006). The importance of personal characteristics in franchisee selection. Journal of Retailing and Consumer Services, 13(2), 133-142. doi:10.1016/j. jretconser.2005.08.008

Combs, J. G., Michael, S., \& Castrogiovanni, G. (2004). Franchising: A review and avenues to greater theoretical diversity. Journal of Management, 30(6), 907-931. doi:10.1016/j.jm.2004.06.006

Dant, R. P., \& Kaufmann, P. J. (2003). Structural and strategic dynamics in franchising. Journal of Retailing, 79(2), 63-75. doi:10.1016/Soo224359(03)00011-3

Davies, M. A. P., Lassar, W., Manolis, C., Prince, M., \& Winsor, R. D. (2011). A model of trust and compliance in franchise relationships. Journal of Business Venturing, 26(3), 321-340. doi:10.1016/j. jbusvent.2009.09.005

Edens, F. N., Self, D. R., \& Grider, D. T. (1976). Franchisors describe the ideal franchisee. Journal of Small Business Management, 14(3), 39-47.

Elango, B., \& Fried, V. H. (1997). Franchising research: A literature review and synthesis. Journal for Small Business Management, 35(3), 68-82.

Emerson, R. W. (1998). Franchise termination: Legal rights and practical effects when franchisees claim the franchisor discriminates. American Business Law Journal, 35(4), 559-645. doi:10.1111/j.1744-1714.1998. tb01015.x

Ennew, C. T., Reed, G. V., \& Binks, M. R. (1993). Importance-performance analysis and the measurement of service quality. European Journal of Marketing, 27(2), 59-70. doi:10.1108/03090569310026402

Fishbein, M. A. (1967). Attitude and the prediction of behavior. In M. Fishbein (Ed.), Readings in attitude theory and measurement ( $\mathrm{pp}$. 477-492). New York, USA: Wiley.

Fishbein, M. A., \& Ajzen, I. (1975). Belief, attitude, intention and behavior. An introdution to theory and research. Reading, USA: Addison-Wesley.

Flint-Hartle, S., \& De Bruin, A. (2011). Franchising success: Insights from real estate brokerage. International Small Business Journal, 29(1), 58-77. doi:10.1177/0266242610369762

Forward, J., \& Fulop, C. (1997). Insights into franchising: A review of empirical and theoretical perspectives. The Service Industries Journal, 17(4), 603-625. doi:10.1080/02642069700000037

Gallini, N., \& Lutz, N. (1992). Dual distribution and royalty fees in franchising. Journal of Law, Economics, \& Organization, 8(3), 471-501.

Gauzente, C. (2003). Measuring franchisees' satisfaction: Theoretical considerations and empirical testing. International Journal of Retail \& Distribution Management, 31(10), 508-517. doi:10.1108/09590550310497030

Guadagnolo, F. (1985). The importance-performance analysis: An evaluation and marketing tool. Journal of Park Recreation Administration, 3(2), 13-22. 
Guilloux, V., Gauzente, C., Kalika, M., \& Dubost, N. (2004). How France's potential franchisees reach their decisions: A comparison with franchisers' perceptions. Journal of Small Business Management, 42(2), 218-224. doi:10.1111/j.1540-627X.2004.00107.x

Harmon, T. R., \& Griffiths, M. A. (2008). Franchisee perceived relationship value. Journal of Business \& Industrial Marketing, 23(4), 256-263. doi:10.1108/08858620810865834

Hawes, J. M., \& Rao, C. P. (1985). Using Importance-Performance Analysis to develop health care marketing strategies. Journal of Health Care Marketing, 5(4), 19-25.

Hing, N. (1995). Franchisee satisfaction: Contributors and consequences. Journal of Small Business Management, 33(2), 12-25.

Hollenhorst, S., Olson, D., \& Fortney, R. (1992). Use of importanceperformance analysis to evaluate state park cabins: The case of the West Virginia state park system. Journal of Park and Recreation Administration, 10(1), 1-11.

Hough, J. (1986). Power and authority and their consequences: A study of the relationships between franchiser and franchisee. Faculty of Management Studies, Polytechnic of Central London, London. Unpublished $\mathrm{PhD}$ thesis.

Jambulingam, T., \& Nevin, J. R. (1999). Influence of franchisee selection criteria on outcomes desired by the franchisor. Journal of Business Venturing, 14(4), 363-395. doi:10.1016/So883-9026(98)00023-8

Jones, G. (2003). Middle East expansion - the case of Debenhams. International Journal of Retail \& Distribution Management, 31(7), 359-364. doi:10.1108/09590550310483323

Justis, R. T. \& Judd, R. J. (2002). Franchising, 2nd ed. Houston, EUA: Dame Publications.

Kaufmann, P. J. (1999). Franchising and the choice of self-employment. Journal of Business Venturing, 14(4), 345-362. doi:10.1016/So8839026(98)00021-4

Kaufmann, P. J., \& Stanworth, J. (1995). The decision to purchase a franchise: A study of prospective franchisees. Journal of Small Business Management, 34(3), 27-40.

Knight, R. (1986). Franchising from the franchisor and franchisee points of view. Journal of Small Business Management, 24(3), 8-15.

Lee, Y., Kim, S., Kim, M., Lee, J., \& Lim, K. (2015). Relational bonding strategies in the franchise industry: The moderating role of duration of the relationship. Journal of Business \& Industrial Marketing, 30(7), 830-841. doi:10.1108/JBIM-10-2013-0237

Lim, J., \& Frazer, L. (2004). Matching franchisor-franchisee roles and competencies. Proceedings of the International Society of Franchising 18th Annual Conference. Las Vegas, USA.

Litz, R. A., \& Stewart, A. C. (1998). Franchising for sustainable advantage? Comparing the performance of independent retailers and trade-name franchises. Journal of Business Venturing, 13(2), 131-150. doi:10.1016/So883-9026(97)00067-0

Martilla, J. A., \& James, J. C. (1977). Importance-performance analysis. Journal of Marketing, 41(1), 77-79. doi:10.2307/1250495

Matzler, K., Bailom, F., Hinterhuber, H. H., Renzl, B., \& Pichler, J. (2004). The asymmetric relationship between attribute-level performance and overall customer satisfaction: A reconsideration of the importanceperformance analysis. Industrial Marketing Management, 33(4), 271277. doi:10.1016/S0019-8501(03)00055-5
Morrison, K. A. (1997). How franchise job satisfaction and personality affects performance, organizational commitment, franchisor relationship, and intention to remain. Journal of Small Business Management, 35(3), 39-63.

Nale, R. D., Rauch, D. A., Wathen, S. A., \& Barr, P. B. (2000). An exploratory look at the use of importance-performance analysis as a curricular assessment tool in a school of business. Journal of Workplace Learning, 12(4), 139-145. doi:10.1108/13665620010332048

Peterson, A., \& Dant, R. P. (1990). Perceived advantages of franchise option from the franchisee perspective: Empirical insights from a service franchise. Journal of Small Business Management, 28(3), 46-61.

Picón, E., Varela, J., \& Braña, T. (2011). La representación de los datos mediante el Análisis de Importancia-Valoración: Problemas y alternativas. Metodología de Encuestas, 13, 121-142.

Pine, R., Hanqin, Q. Z., \& Qi, P. (2000). The challenges and opportunities of franchising in China's hotel industry. International Journal of Contemporary Hospitality Management, 12(5), 300-307. doi:10.1108/09596110010339670

Ramírez, J. M., Rondán, F. J., Guerrero, F. M., \& Berbel, J. M. (2011). Identifying the franchisee profiles franchisors prefer. Journal of Business Economics and Management, 12(4), 567-588. doi:10.3846 /16111699.2011.599408

Ramírez, J. M., \& Quattrociocchi, B. (2009). An update of the franchisee motivations: A study in Spain. Journal of Applied Economic Sciences, $8,210-220$.

Roh, E., \& Yoon, J. H. (2009). Franchisor's ongoing support and franchisee's satisfaction: A case of ice cream franchising in Korea. International Journal of Contemporary Hospitality Management, 21(1), 85-99. doi:10.1108/09596110910930205

Sampson, S. E., \& Showalter, M. J. (1999). The performance-importance response function: Observations and implications. Service Industries Journal, 19(3), 1-25. doi:10.1080/02642069900000027

Sethna, B. N. (1982). Extensions and testing of importance-performance analysis. Business Economics, 17(4), 28-31.

Shivell, K., \& Banning, K. (1995). The franchise kit. New York, USA: McGraw-Hill.

Slack, N. (1994). The importance-performance matrix as a determinant of improvement priority. International Journal ofOperations \& Production Management, 14(5), 59-75. doi:10.1108/01443579410056803

Sorenson, O., \& Sørensen, J. B. (2001). Finding the right mix: Franchising, organizational learning, and chain performance. Strategic Management Journal, 22(6-7), 713-724. doi:10.1002/smj.185

Stanworth, J. (1985). The School of Management Studies of the Polytechnic of Central London. In M. Mendelsohn (Ed.), The Guide to Franchising. Oxford, U.K.: Pergamon Press.

Stanworth, J., \& Purdy, D. (1994). The impact of franchising on the development prospects of Small and Medium-Sized Enterprises (SME's) in Europe. Paper (4), International Franchise Research Centre, Special Studies Series.

Stanworth, J., Stanworth, C., Granger, B., \& Blyth, S. (1989). Who becomes an entrepreneur?. International Small Business Journal, 8(1), 11-22. doi:10.1177/026624268900800101

Tatham, R. L., Douglas, R., \& Bush, R. F. (1972). An analysis of decision criteria in franchisor/franchisee selection processes. Journal of Retailing, 48(1), 16-22.

Tormo Franchise Consulting. (2014). Informe de la franquicia 2014. Retrieved from www.tormofranchise.com 
Viera, V. A., \& Slongo, L. A. (2007). Relación entre franquicia y franquiciado. Se proponen dos modelos. Revista Científica Esic-Market, 123, 133-160.

Weavin, S., \& Frazer, L. (2007). Expansion through multiple unit franchising:Australian franchisors revealtheirmotivations. InternationalSmall Business Journal, 25(2), 173-205. doi:10.1177/0266242607074524
Williamson, G. (1995). Franchising in Australia, 2nd ed. St Leonard's, Australia: Allen \& Unwin Pty Ltd.

Withane, S. (1991). Franchising and franchisee behavior: An examination of opinions, personal characteristics, and motives of canadian franchisee entrepreneurs. Journal of Small Business Management, 29(1), 22-29. 